UDK: 37.06:364.271

Izvorni naučni rad

Primljeno: 11.3.2019.

Prihvaćeno za štampu: 31.5.2019.

mr Smaila Balić, asistent

Univerzitet u Bihaću

Islamski pedagoški fakultet

balicsmaila@gmail.com

\title{
VRŠNJAČKO NASILJE I PREVENTIVNI PROGRAM
}

\section{Sažetak}

S ciljem da se ukaže na važnost proučavanja problema vršnjačkog nasilja te prevencije istog, u ovom radu ćemo pružiti pregled karakteristika vršnjačkog nasilja, osnovne determinante ovog problema, njegove dosadašnje posljedice te pregled podataka prikupljenih iz različitih istraživanja.

Cilj rada je ispitati potrebu za izradu preventivnog programa za vršnjačko nasilje na osnovu procesa procjena potreba. Riječ je zapravo o modelu ulaganja u pozitivan i siguran razvoj mladog čovjeka unutar školskih ustanova, budući da su djeca i mladi važan interes zajednice.

Ključne riječi: faktori rizika, intervencija, prevencija, tiho nasilje, vršnjačko nasilje

\section{Uvod}

Vršnjačko nasilje je česta pojava iako se ovoj pojavi ne posvećuje dovoljno pažnje. Posljedica toga vjerovatno jeste činjenica da su se donedavno ponašanja koja se danas opisuju kao vršnjačko nasilje, smatrala sastavnim dijelom ljudskog razvoja, odnosno prolaznom fazom koja je karakteristična za djetinjstvo.

Do promjene u stavu prema vršnjačkom nasilju došlo je 1972. godine kada je švedski liječnik po imenu Heinemann zabilježio svoja zapažanja o nasilju među skupinom djece na školskom igralištu. Heinemannova studija je prvo istraživanje nasilja među školskom djecom - ponašanja koje je on nazvao i opisao kao mobbing. (Rivers, Duncan i Besag, 2007; 
prema Sesar 2011) Poslije ovog istraživanja uslijedila su i ostala u kojima je proširen opseg ponašanja povezanih s nasiljem među djecom (eng.bullyingom). Nakon istraživanja u sljedeće procjene bivaju uključeni širenje tračeva, socijalna izolacija, destrukcija te gubitak ili krađa osobnog vlasništva.

Nakon istaknute problematike, došlo je do povećanog zanimanja za pojave vezane za vršnjačko nasilje kao i brojna istraživanja. I dok je na našim područjima problem vršnjačkog nasilja tek u početnim fazama istraživanja, odnosno u fazi utvrđivanja raširenosti pojave, u razvijenim zemljama svijeta problem vršnjačkog nasilja je prošao kroz nekoliko faza: od utvrđivanja učestalosti pojave, rada na senzibilizaciji javnosti za ovaj problem, svijesti o potrebi za interdisciplinarnim pristupom problemu, povećanom angažmanu, nadležnih institucija, prikupljanju sredstava i podrške vladajućih institucija, izrade prevencijskih i intervencijskih programa te konačno evaluaciji prevencijskih i intervencijskih programa. (Sesar, 2011)

S ciljem da se ukaže na važnost proučavanja problema vršnjačkog nasilja, te prevencije istog, predstavit ćemo u ovoj procjeni potreba podatke dobivene iz istraživanja u osnovnim školama i podatke iz relevantnih institucija koje tretiraju ovaj problem.

\section{Vršnjačko nasilje}

Dijete je zlostavljano kada je učestalo i trajno izloženo negativnim postupcima od strane jednoga ili više djece. U okviru definicije ističu se tri bitna elementa:

- trajanje,

- negativni postupci i

- neravnopravan odnos snaga. (Olwes, 1998)

U definiciji se naglašava trajnost i ponavljanje negativnih postupaka. Pod negativnim postupcima podrazumijeva se djelovanje pojedinca kada on namjerno zadaje ili nastoji zadati ozljedu ili bilo kakvu neugodnost drugom pojedincu. Dijete koje je izloženo nasilju teško se brani i donekle je bespomoćno u odnosu prema onome ko se nasilno ponaša. (Sesar, 2011) 
Međutim neki autori ne smatraju da glavno obilježje vršnjačkog nasilja mora biti trajanje i ponavaljanje negativnih posljedica, pa tako Lejn (1988) definiše nasilje kao bilo koje djelo čija je namjera da se izazove strah ili nelagodnost, odnosno da je nasilje agresivno ponašanje koje je proisteklo iz svjesne namjere da se izazove fizička ili psihološka patnja drugih. (Rendal, 1997).

$\mathrm{Na}$ različite načine pokušalo se odrediti podvrste ili oblike vršnjačkog nasilja, odnosno u nekim slučajevima agresivnosti među djecom općenito. Vršnjačko nasilje najčešće se dijeli u dva glavna oblika:

- tjelesno i

- verbalno. (Sesar, 2011)

Pored ovih navode se i sljedeći oblici vršnjačkog nasilja: socijalno, seksualno, psihološko, kulturalno, ekonomsko, elektronsko nasilje, zadirkivanje, uznemiravanje.

Tjelesno nasilje je najuočljiviji oblik te podrazumijeva udaranje, guranje, štipanje i sl. Verbalno nasilništvo najčešće prati tjelesno, a podrazumijeva vrijeđanje, širenje glasina, stalno zadirkivanje. U navedenim oblicima nasilja mogu se izdvojiti četiri podvrste nasilnog ponašanja: emocionalno nasilništvo koje je usko povezano s prijašnja dva te uključuje namjerno isključivanje djeteta koje je izloženo nasilnom ponašanju iz zajedničkih aktivnosti razreda ili dječje grupe; ignoriranje; kulturalno nasilništvo koje podrazumijeva vrijeđanje na nacionalnoj, religijskoj i rasnoj osnovi, i posljednje, ekonomsko nasilništvo koje uključuje krađu i iznuđivanje novca (Bilić i Karlović, 2004). Crick i Grotpeter (1995) navode da postoji razlika između tjelesne ili očevidne agresije i relacijske agresije. Relacijsku agresiju definirali su kao povređivanje drugih kroz svrhovitu manipulaciju i oštećivanje odnosa, dok je tjelesna agresija definirana u skladu s neskrivenim aktivnostima, kao što su udaranje i guranje. Međutim, trebamo se zapitati može li tjelesno ponižavanje nekog djeteta istovremeno imati i namjeru da se to dijete liši potpore od strane druge djece, odnosno može li izloženost tjelesnoj agresiji za posljedicu imati utjecaj na samopoštovanje i/ili socijalni status djeteta. (Sesar, 2011)

Posljedice vršnjačkog nasilja mogu se pokušati grupirati u tri kategorije: 
- psihološke poteškoće,

- poteškoće u socijalnom funkcioniranju i

- tjelesne posljedice. (Sesar, 2011)

Razlikuju se tri oblika vršnjačkog nasilja:

1. verbalno nasilje (poput vrijeđanja, nadijevanja pogrdnih imena, omalovažavanja, kritiziranja, sramoćenja i seksualnih dobacivanja)

2. fizičko nasilje (šamaranje, udaranje, davljenje, bockanje, štipanje, guranje, udarci nogom, šakom, ugrizi, grebanje, pljuvanje, oštećivanje ili uništavanje odjeće ili imovine žrtve)

3. nasilje kroz odnose (ignoriranje, izolacija, isključivanje ili izbjegavanje). (Sesar, 2011)

Kod drugog navedenog pristupa klasifikacije nasilnog ponašanja potrebno je spomenuti Olweusa (1998) koji razlikuje dvije vrste nasilništva: izravna i neizravna nasilnička ponašanja. U izravne oblike nasilja ubrajaju se svi direktni i otvoreni napadi na žrtvu, bilo verbalni ili fizički, poput izrugivanja, psovanja i vrijeđanja ili pak guranja, šamaranja, udaranja i sl. Neizravni oblici nasilja među djecom su suptilniji i teže ih je uočiti, a uključuju ignoriranje, isključivanje iz društva i sl.

Četiri su karakteristična profila koja se mogu razlikovati u okviru vršnjačkog nasilja:

- djeca koja su izložena nasilju,

- djeca koja se nasilno ponašaju,

- djeca koja doživljavaju nasilje, ali ga i sami čine te

- djeca koja ni na koji način ne sudjeluju u vršnjačkom nasilju (Salmivalli i sur., 1996.)

Istraživanja su pokazala da počinitelje nasilja karakterizira nedostatak razumijevanja za ono što im je rečeno, sumnjičavost, kompulzivna potreba da kontroliraju druge (Field, 1999 prema Puharić, Baričević 2014). Zatim, smatraju da će postići uspjeh ako budu agresivni, izbor žrtve opravdavaju provokacijom od strane žrtve ili jednostavno zato što 
ne vole osobu koju biraju za žrtvu (Boulton i Underwood, 1992 prema Sesar 2011). Slee i Rigby (1993) utvrdili su da su počinitelji vršnjačkog nasilja emocionalno nezreliji, imaju poteškoća u uspostavljanju i održavanju intimnih odnosa, manje su empatični, imaju česte promjene raspoloženja, lako se razljute, te nemaju osjećaj grižnje savjesti.

Djeca koja doživljavaju nasilje, karakterizira depresivnost, anksioznost, nesigurnost i sklonost samoubistvu. Imaju nisko samopouzdanje i samopoštovanje, pasivne su, a javlja se i tendencija da sebe okrivljuju za poteškoće. Njihove socijalne vještine lošije su u odnosu na ostalu djecu (Mynrad i Joseph, 1997 prema Sesar, 2011).

Djeca koja trpe nasilje, ali se i nasilno ponašaju prema drugima, imaju slabije samopoštovanje, imaju veći rizik za različite oblike problema $\mathrm{u}$ ponašanju kao što su: hiperaktivnost, agresivnost, ovisnost o alkoholu, delinkvencija i izbjegavanje roditeljskih pravila (Schwartz, 2000 prema Sesar, 2011).

Kada znamo ove podatke imamo i viziju na koji bismo način mogli djelovati na preveniranju vršnjačkog nasilja, budući da nasilničko ponašanje gotovo uvijek se događa u prisutnosti vršnjaka, te ovisno o njihovoj prisutnosti i ulogama koje imaju, vršnjaci mogu utjecati na ishod nenasilničkog ponašanja (Swear i Esspallage, 2004; prema Vejmelka 2012).

\section{Procjena potreba}

U ovom dijelu rada analizirat će se prikupljeni podaci iz sljedećih izvora:

-Federalni zavod za statistiku $(\mathrm{FBiH})$

-Centra za socijalni rad Bihać

-Osnovnih škola na području grada Bihaća (urbani dio)

-Ministarstva unutrašnjih poslova (MUP USK)

Osim navedenih izvora temelj rada bit će nam dosadašnja istraživanja o vršnjačkom nasilju na našim područjima. Posebno treba napomenuti da su podaci prikupljeni po različitim resursima i različitom metodologijom. Prikazi pojedinih parametara su također različiti. Kroz rad ćemo navesti i prepreke s kojima smo se susretali u prikupljanju 
podataka od strane određenih institucija. Napravilo se ono što je bilo moguće, pa neka ovi prikupljeni podaci, način njihova prikupljanja, analize i predstavljanja podataka posluže da se na ovom području (prevenciji vršnjačkog nasilja) učine određeni pomaci i tako doprinese praćenju stvarnog stanja i mogućnosti njegove prevencije.

\section{Opći epidemiološki podaci o broju djece u osnovnim školama na području općine Bihać}

Prema podacima federalnog zavoda za statistiku na području Federacije Bosne i Hercegovine u školskoj godini 2016./2017. djelovalo je 1.078 redovnih osnovnih škola (matične i samostalne sa područnim školama). U školskoj godini 2015./2016. broj razrednih odjeljenja/odjela se razlikuje u odnosu na školsku godinu 2016./2017. za 155. Broj učenika u školskoj godini 2016./2017. u odnosu na školsku godinu 2015./2016. manji je za 1.2\% (2.258). Udio učenica u ukupnom broju učenika je nepromijenjen i iznosi 48,38\%. Odnos broja nastavnog osoblja i učenika u redovnom obrazovanju u školskoj godini 2016./2017. iznosi $1: 12,54$. Udio žena u ukupnom broju nastavnog osoblja iznosi 72.27\%.

Budući da se istraživanje usmjerilo na vršnjačko nasilje u osnovnim školama, odnosno na razrede od šestog do devetog, iz Federalnog zavoda za statistiku predstavit ćemo broj upisanih učenika iz 2015./2016. i 2016./2017. školske godine, kako bismo znali broj djece u osnovnim školama, od šestog do devetog razreda kao i podatke o školama, odjeljenjima i nastavnicima općine Bihać.

Tablica 1.Statistički bilten (Zavod za statistiku FBiH)

\begin{tabular}{l|l|l|l|l} 
Općina Bihać & Škole & Odjeljenja & Učenici & Nastavnici \\
\hline $2015 . / 2016$. & 32 & 264 & 4976 & 399 \\
2016./2017. & 32 & 254 & 4653 & 386
\end{tabular}

Prisutna je tendencija smanjivanja broja odjeljenja, učenika i nastavnika. Nedostatak predstvalja što se neki podaci ne prate, kao što je vidiljivo iz Zavoda za statistiku u FBiH. Ne prati se stopa vršnjačkog nasilja, kao ni opravdani i neopravdani izostanci u školama, nagrade, negativne sankcije niti struktura porodica učenika, što bi svakako bilo korisno za sva buduća istraživanja koja imaju dodirnih tačaka sa djecom i mladima i njihovim problemima. 


\section{Podaci iz Centra za socijalni rad Bihać}

Iz Centra za socijalni rad nisu bili u mogućnosti da nam pruže velike podatke budući da prema njihovim navodima nisu imali toliko prijava. Oni intervenišu u krajnjem slučaju, a svi postupci se vode između škola i policije, kako se navodi u Protokolu o postupanju nasilja u školi.

Podaci koje je Centar imao zabilježene u vezi vršnjačkog nasilja su sljedeći:

- 2016. godine zabilježena je jedna prijava vršnjačkog nasilja. Radi se o muškoj osobi starosti 10 godina iz urbane sredine, a prijava je bila od strane majke djeteta

- u 2017. godini prijava od strane škole, a radi se o istom djetetu.

Kada na red dođe da Centar za socijalni rad mora intervenisati po pitanju vršnjačkog nasilja, a to se dešava kada škola smatra da je potrebno uključiti i druge stručnjake osim onih s kojima ona raspolaže, onda Centar za socijalni rad sa počiniteljem nasilja provode odgojne preporuke. Kada se desi vršnjačko nasilje, relacija je: škola, dom zdravlja, policija. U Centru za socijalni rad Bihać provode se samo dvije odgojne preporuke: lično izvinjenje oštećenoj strani $i$ rad $u$ humanitarne svrhe u lokalnoj zajednici.

Postavlja se pitanje da li su zaista samo dvije odgojne preporuke i način njihove realizacije dovoljni da se koriguje socijalno neprihvatljivo ponašanje maloljetnika?

S obzirom da je za pojavu vršnjačkog nasilja i način njegova rješavanja vezano više izvora, cilj istraživanja je dobiti potpuni uvid u podatke s kojima raspolažu nadležne institucije.

\section{Podaci iz Ministarstva unutrašnjih poslova}

Tablica 2. Statistički podaci vršnjačkog nasilja na području općine Bihać u periodu od 2015-2017. godine

\begin{tabular}{l|l|l|l|l} 
Bihać & $\begin{array}{l}\text { Prijave } \\
\text { vršnjačkog } \\
\text { nasilja }\end{array}$ & $\begin{array}{l}\text { Krivično } \\
\text { djelo }\end{array}$ & Prekršaj & $\begin{array}{l}\text { Ostali } \\
\text { događaji }\end{array}$ \\
\hline 2015 godina & 47 & 16 & 7 & 24
\end{tabular}




\begin{tabular}{l|l|l|l|l}
2016 godina & 19 & 6 & 3 & 10 \\
2017 godina & 3 & 2 & 1 & - \\
Ukupno & $\mathbf{6 9}$ & 24 & 11 & 34
\end{tabular}

Rezultat smanjenja vršnjačkog nasilja iz godine u godinu je vjerovatno posljedica djelovanja Ministarstva unutrašnjih poslova USK. „Ohrabruje podatak da je u 2017. došlo do pada vršnjačkog nasilja u školama za čak 31.5\% i mi smo kontinuirano radili i sa stručnim osobama i sa osobama koje rade u odgojno-obrazovnim ustanovama tako da smo i kroz edukaciju policijskih službenika i uposlenika $\mathrm{u}$ Ministarstvu obrazovanja, napravili jedan, može se reći, dobar posao.“ (Anel Ramić, ministar unutrašnjih poslova USK).

Tablica 3. Počinioci vršnjačkog nasilja po spolnoj i starosnoj strukturi na području općine Bihać u periodu od 2015-2017. godine

\begin{tabular}{l|l|l|l|l|l|l|l} 
Bihać & $\begin{array}{l}\text { Počinio } \\
\text { ci } \\
\text { vršnjač } \\
\text { kog } \\
\text { nasilja }\end{array}$ & $\begin{array}{l}\text { Muški } \\
\text { spol }\end{array}$ & $\begin{array}{l}\text { Žensk } \\
\text { i spol }\end{array}$ & $\begin{array}{l}\text { Do } \\
\mathbf{1 4 . g o d} \\
\text { ina }\end{array}$ & $\begin{array}{l}\text { Od } \\
\mathbf{1 4 - 1 6} \\
\text { godin } \\
\text { a }\end{array}$ & $\begin{array}{l}\text { Od } \\
\mathbf{1 6 - 1 8} \\
\text { godin } \\
\text { a }\end{array}$ & $\begin{array}{l}\text { Preko } \\
\mathbf{1 8} \\
\text { godin } \\
\text { a }\end{array}$ \\
\hline $\begin{array}{l}2015 \\
\text { godina }\end{array}$ & 60 & 43 & 17 & 5 & 19 & 31 & 5 \\
$\begin{array}{l}2016 \\
\text { godina }\end{array}$ & 27 & 23 & 4 & 9 & 7 & 9 & 2 \\
$\begin{array}{l}2017 \\
\text { godina }\end{array}$ & 3 & 3 & - & 1 & - & 2 & -
\end{tabular}

Dosadašnja istraživanja (Seals i Young, 2003.; Yang i sur.,2006.; Forero i sur., 1999; Craig, 1998.; Crick i Bigbee, 1998.; Crick i Grotpeter, 1995) pokazuju da je najviše počinioca vršnjačkog nasilja muškog spola, te da ih je najviše iz starosne dobi od 16 do 18 godina, kao i da djevojčice imaju efikasnije strategije u suočavanju sa vršnjačkim nasilje nego dječaci.

Kao podnosioci prijava vršnjačkog nasilja javljaju se: roditelji, obrazovne institucije, centar za socijalni rad i žrtva. 
Tablica 4. Prijave vršnjačkog nasilja

\begin{tabular}{l|l|l|l|l|l} 
Bihać & $\begin{array}{l}\text { Prijava } \\
\text { od strane } \\
\text { roditelja }\end{array}$ & $\begin{array}{l}\text { Prijava } \\
\text { od strane } \\
\text { obrazovn } \\
\text { ih } \\
\text { institucij } \\
\text { a }\end{array}$ & $\begin{array}{l}\text { Prijava } \\
\text { centra za } \\
\text { socijalni } \\
\text { rad }\end{array}$ & $\begin{array}{l}\text { Prijava } \\
\text { od strane } \\
\text { žrtve }\end{array}$ & $\begin{array}{l}\text { Prijava } \\
\text { od strane } \\
\text { ostalih }\end{array}$ \\
\hline $\begin{array}{l}2015 \\
\text { godina }\end{array}$ & 25 & 12 & 1 & - & 9 \\
$\begin{array}{l}2016 \\
\text { godina }\end{array}$ & 11 & 3 & 1 & 1 & 3 \\
$\begin{array}{l}2017 \\
\text { godina }\end{array}$ & 1 & 2 & - & - & -
\end{tabular}

Žrtve se teško odlučuju prijaviti nasilje, a razlozi mogu biti mnogobrojni i tema nekog drugog istraživanja.

Nakon zaprimanja prijave vršnjačkog nasilja ovlaštena službena lica prvenstveno postupaju u skladu sa Zakonom o policijskim službenicima Unsko-sanskog kantona kao i drugim odgovarajućim propisima kao što je Krivični zakon FBiH, Zakon o krivičnom postupku FBiH, Zakon o prekršajima, zatim Zakon o zaštiti i postupanju sa djecom i maloljetnicima u krivičnom postupku.

Podaci koji su do sada predstavljeni su statistički podaci o vršnjačkom nasilju koje uključuje fizičko zlostavljanje. Iz tih razloga provedeno je istraživanje u tri osnovne škole na području općine Bihać, sa učenicima od šestog do devetog razreda, gdje je cilj istraživanja bio ispitati prisutnost tihog nasilja za kojeg nisu predviđene nikakve zakonske sankcije nego je sprječavanje tog nasilja polje djelovanja učitelja i odgajatelja, te drugih stručnih lica odgojno-obrazovnih institucija.

\section{Analiza podataka dobivenih iz osnovnih škola}

Vršnjačko nasilje definira se kao izloženost namjerno negativnom, ponavljanom djelovanju jednog ili više učenika, nerazmjerne stvarne ili percipirane snage, zbog koje dijete trpi tjelesnu i/ili emocionalnu štetu, a nemoćno je da se odupre. (Puharić, Baričević, 2014)

Dakle anketa je bila provedana u nekoliko odjeljenja među učenicima različite dobi, od šestog do devetog razreda. Anketni uzorak je bio 152 
učenika ( $\mathrm{N}=152)$ kojima je ponuđena anketa za vrijeme trajanja nastave. Anketa koja je korištena u ovom istraživanju je anketa novinarske sekcije SŠ „Uskoplje“ koju smo redizajnirali, odnosno prilagodili potrebama našeg istraživanja. Anketa se sastojala od 16 pitanja s ponuđenim odgovorima: nikad, ponekad i često.

\section{Analiza podataka}

Spol: ženskih ispitanika je bilo $75 \%$, a muških ispitanika $25 \%$.

Dobiveni su sljedeći podaci:

Tablica 5. Statistički podaci o prisutnosti vršnjačkog nasilja u osnovnim školama na području općine Bihać

\begin{tabular}{l|c|c|c}
\multicolumn{1}{c|}{ Pitanja: } & Nikad & Ponekad & Često \\
\hline $\begin{array}{l}\text { Drugi učenici me } \\
\text { ušutkavaju kada }\end{array}$ & $55.6 \%$ & $38.9 \%$ & $5.6 \%$ \\
$\begin{array}{l}\text { želim nešto réci } \\
\text { Neki učenici me } \\
\text { zadirkivaju }\end{array}$ & $33.3 \%$ & $33.3 \%$ & $33.3 \%$ \\
$\begin{array}{l}\text { Neki učenici mi se } \\
\text { rugaju }\end{array}$ & $66.7 \%$ & $30.6 \%$ & $2.8 \%$ \\
$\begin{array}{l}\text { Dobio sam batine } \\
\text { od drugih učenika }\end{array}$ & $97.2 \%$ & $2,8 \%$ & - \\
$\begin{array}{l}\text { Drugi učenici me } \\
\text { primoravaju da } \\
\text { im činim sitne }\end{array}$ & $72.2 \%$ & $25 \%$ & $2.8 \%$ \\
$\begin{array}{l}\text { usluge } \\
\text { Jaki učenici mi se } \\
\text { rugaju }\end{array}$ & $75 \%$ & $22.2 \%$ & $2.8 \%$ \\
$\begin{array}{l}\text { Mnogi učenici me } \\
\text { izbjegavaju }\end{array}$ & $69.4 \%$ & $22.2 \%$ & $8.3 \%$ \\
$\begin{array}{l}\text { Neki učenik/ca me } \\
\text { nazvao/la } \\
\text { pogrdnim } \\
\text { imenima }\end{array}$ & $66.7 \%$ & $30.6 \%$ & $2.8 \%$ \\
$\begin{array}{l}\text { Neki učenik/ca je } \\
\text { prijetio/la meni } \\
\text { Neki učenik/ca je } \\
\text { ogovarao/la mene }\end{array}$ & $28.6 \%$ & $57.1 \%$ & $14.3 \%$ \\
\end{tabular}




\begin{tabular}{|c|c|c|c|}
\hline $\begin{array}{l}\text { Neki učenik/ca je } \\
\text { namjerno } \\
\text { gurnuo/la mene }\end{array}$ & $55.6 \%$ & $41.7 \%$ & $2.8 \%$ \\
\hline $\begin{array}{l}\text { Neki učenik/ca je } \\
\text { namjerno } \\
\text { udario/la mene }\end{array}$ & $72.2 \%$ & $25 \%$ & $2.8 \%$ \\
\hline $\begin{array}{l}\text { Prijavio/la sam } \\
\text { nasilje odrasloj } \\
\text { osobi (roditelj, } \\
\text { nastavnik, } \\
\text { pedagog) }\end{array}$ & $48.6 \%$ & $34.3 \%$ & $17.1 \%$ \\
\hline $\begin{array}{l}\text { Smatram da } \\
\text { postoji nasilje u } \\
\text { našoj školi, ne } \\
\text { osjećam se } \\
\text { sigurno }\end{array}$ & $57.1 \%$ & $34.3 \%$ & $8.6 \%$ \\
\hline $\begin{array}{l}\text { U školi se } \\
\text { osjećam sigurno, } \\
\text { znam da će } \\
\text { nasilnici biti } \\
\text { kažnjeni }\end{array}$ & $11.1 \%$ & $27.8 \%$ & $61.1 \%$ \\
\hline
\end{tabular}

Ovi rezultati pokazuju da u osnovnim školama na području Bihaća u urbanim sredinama, trenutno nema fizičkog vršnjačkog nasilja, iako podaci pokazuju da se $41.7 \%$ učenika izjasnilo da su ih drugi učenici ponekad namjerno gurnuli. Međutim, nijedan učenik se nije izjasnio da je dobio batine od drugih učenika, tako da ipak možemo zaključiti da fizičkog nasilja među učenicima nema, ali da je tiho nasilje ipak prisutno, koje se ogleda u ogovaranju, podsmijavanju, ruganju, izbjegavanju, nazivanju pogrdnim imenima i slično. Ipak 57.1\% učenika smatra da u njihovoj školi ne postoji nasilje i da se osjećaju sigurno, dok njih 34.3\% ponekad se ne osjećaju sigurno u školi, što je dovoljan pokazatelj da ipak ima prostora za djelovanje u saniranju i preveniranju vršnjačkog nasilja. Svakako da je ovoj stopi smanjenja vršnjačkog nasilja pridonijelo organizovano djelovanje stručnih timova u nadležnosti Ministarstva obrazovanja i Ministarstva unutrašnjih poslova USK-a.

Ovi podaci ukazuju da bi se u ovim školama mogao primijeniti model preventivnog programa protiv tihog vršnjačkog nasilja, ali i ostalih 
oblika nasilja ako se u obzir uzme da učenici možda daju socijalno poželjne odgovore.

Nakon što se provela anketa sa učenicima, pristupilo se intervjuisanju razrednika šestih i devetih odjeljenja. Intervju se obavio sa njih 8 , pet ispitanika muškog spola i tri ženskog spola. Pitanja intervjua bila su sljedeća:

- Koliko često vam učenici kažu da su bili zlostavljani?

- Smatrate li da su učenici zlostavljani na školskim hodnicima, idući u školu i vraćajući se iz nje?

- Od početka ove školske godine, koliko često ste razgovarali s vašim učenicima o nasilničkom ponašanju prema drugima?

- Od početka školske godine, koliko često ste razgovarali sa učenicima o nasilničkom ponašanju nad njima?

- Šta mislite koliko je postotak učenika u vašoj školi za koje vjerujete da su zlostavljali druge učenike jednom sedmično ili više, od početka ove školske godine?

Većina nastavnika/razrednika se izjasnila da nisu imali priliku čuti od svojih učenika da su zlostavljani. Ako se dese neki sukobi, učenici ih među sobom rješavaju, misleći pritom na neke nesuglasice. Svađe i neslaganja nastavnici vide kao sastavni proces odrastanja i prolaska kroz period osnovne škole. Većina njih ne vjeruje da su učenici zlostavljani niti u školi, niti kada idu ili se vraćaju iz škole. O nasilničkom ponašanju razgovaraju kroz proces nastave, a predviđene su i neke lekcije o nasilju Nastavnim planom i programom za Odjeljensku zajednicu. Što se tiče postotka učenika koji zlostavljau druge učenike smatraju da je taj procenat mali oko 5-10\% u odnosu na ostale učenike. Budući da škola osim što je faktor zaštite može biti i faktor rizika, u ovom slučaju potvrđeno je da se nastavnici i cijeli odgojno-obrazovni sistem osnovnih škola bori protiv vršnjačkog nasilja. Iz tih razloga poželjno je da se izradi preventivni program koje će ove škole usvojiti kako bi se stanje u potpunosti saniralo jer za to postoji dobra podloga, na što ukazuju rezultati istraživanja.

Riječ je zapravo o modelu ulaganja u pozitivan i siguran razvoj mladog čovjeka unutar školskih ustanova, budući da su djeca i mladi važan interes zajednice. 
$\mathrm{Na}$ osnovu podataka dobivenih iz istraživanja zadatak je projekta predložiti sveobuhvatne prevencijske intervencije vršnjačkog nasilja. Svakako da bi u tome najvažniju ulogu imao tim odnosno stručna pomoć u implementaciji projekta, koji bi bio zadužen za aktivnosti projekta, njihovu realizaciju i evaluaciju. Važna je i saradnja institucija - niti jedna institucija u zajednici ne može sama obuhvatiti i odgovoriti na potrebe djece i mladih. Potrebna je saradnja među svim subjektima u zajednici, kojima je fokus djelovanja djeca i mladi (odgojnoobrazovne institucije, policija, centar za socijalni rad, vijeće učenika, vijeće roditelja, mediji) kojima bi cilj bio

- reduciranje stepena rizika $\mathrm{i}$

- jačanje zaštitnih faktora na razini pojedinaca i njihovih okruženja u vrijeme odrastanja djece i mladih te na taj način promovirati zdrav razvoj.

Intervencije (koje mogu poslužiti kao podloga za izradu preventivnog programa):

- jačanje socijalnih vještina

- nenasilno rješavanje sukoba

- edukacije vještina razgovaranja i kontrolisanja emocija

- izgradnja negativnih stavova prema nasilju

- jačanje normi škole i uvođenja primjerenih kazni

- uključivanje roditelja u određene edukacijske programe

Nužnost je u djelovanju na sva okruženja djece i mladih, stvaranja partnerstva između svih bitnih institucija koje su vezane za problem vršnjačkog nasilja.

\section{Ograničenja:}

-podaci koje razne službe u zajednici evidentiraju kroz vlastiti rad ne predstavljaju epidemiološku sliku pojavnosti

-stvarni podaci o rasprostranjenosti mogu se dobiti jedino provođenjem odgovarajućih epidemioloških istraživanja 


\section{Zaključci uprkos ograničenjima:}

-postoji broj djece i mladih (podaci istraživanja pokazuju) koji su u potrebi za prevencijskim intervencijama vršnjačkog nasilja.

\section{Zaključak}

S obzirom da bi svaka zajednica na temelju vlastitih snaga $\mathrm{i}$ procijenjenih potreba trebala organizirati ulaganje napora u smjeru pozitivnog razvoja djece i mladih (Bašić, 2007) tako i naša lokalna zajednica bi se trebala usmjeriti na prevenciju vršnjačkog nasilja. Vršnjačko nasilje je složen problem i fenomen koji ne zavisi samo o osobnim karakteristikama pojedinca nego i o odgojnim postupcima unutar obitelji, strukture porodičnih odnosa, kao i o situacijskoj klimi unutar zajednice, uključujući na prvom mjestu odgojno-obrazovne institucije. Ovo nasilje za sobom ostavlja mnogobrojne posljedice, budući da je učestvovanje u vršnjačkom nasilju prediktor kratkotrajnih i dugotrajnih psiholoških poteškoća kako kod žrtve tako i kod počinitelja nasilja. Iz tih razloga predviđena je faza izrade preventivnog modela, odnosno prevencijskog programa za vršnjačko nasilje. Svakako da je ovo problem u čijem rješavanju učešća mogu i moraju uzeti sve neophodne institucije i ličnosti. Potrebno je provoditi treninge i kontinuirane edukacije o karakteristikama vršnjačkog nasilja, kratkotrajnim i dugoročnim posljedicama te oblicima intervencija koje su efikasne za reduciranje vršnjačkog nasilja, a u koje bi bili uključeni nastavnici i zdravstveni djelatnici. Osim toga, trebalo bi raditi na podizanju javne svijesti o vršnjačkom nasilju i njegovim posljedicama kroz različite oblike javnih kampanja.

\section{Literatura}

1. Bašić, J. (2010). Zajednice koje brinu: model prevencije poremećaja u ponašanju djece i mladih: razvoj, implementacija i evaluacija prevencije u zajednici. Zagreb - Pula: Edukacijsko-rehabilitacijski fakultet

2. Olweus, D., Endresen, I.M. (1998). The importance of sex-of-stimulus object: Age trends and sex differences in empathic responsivness. Social Development 
3. Puharić, Z. i Baričević, M. (2014). Vršnjačko nasilje u osnovnim školama Bjelovarsko-bilogorske županije. Bjelovar: Visoka tehnička škola u Bjelovaru

4. Salmivalli, C., Karhunen, J., Lagerspetz, K.M.J. (1996). How do the victims respond tobullying? Aggressive Behavior

5. Sesar, K. (2011) Obilježja vršnjačkog nasilja. Široki Brijeg: Centar za mentalno zdravlje

6. Sesar, K. i Šimić, N. (2011) Vršnjačko nasilje i strategije suočavanja kod djece osnovnoškolske dobi. Mostar: Filozofski fakultet, Odsjek za psihologiju

7. Slee, P.T., Rigby, K. (1993). Australian school children's self appraisal of interpersonal relations: The bullying experience. Child Psychiatry and Human Development

8. Vejmelka, L. (2012). Neke determinante vršnjačkog nasilja u adolescenciji. Zagreb: Studijski centar socijalnog rada

9. Federalni zavod za statistiku $(\mathrm{FBiH})$ 


\section{Smaila Balić, M.A.}

University of Bihac

Islamic pedagogical faculty

balicsmaila@gmail.com

Original scientific article

\section{BULLYING AND PROGRAM OF PREVENTION}

\section{ABSTRACT}

In order to point out the importance of studying the problem of bullying and prevention of the same, in this paper we will provide an overview of the characteristics of bullying, the basic determinants of this problem, its previous consequences, and the overview of data collected from various research.

The aim of the paper is to examine the need for the development of a preventive program for bullying based on process of needs assessment. This is actually a model of investment in positive and safe development of a young man within school institutions, since children and young people are an important community interest.

Keywords: risk factors, intervention, prevention, silent violence, bullying 


$$
\begin{aligned}
& \text { ماجستير العلوم سيدة سمائلة باليتش } \\
& \text { جامعة بيهاتش } \\
& \text { كلية التربية الإسلامية }
\end{aligned}
$$

\section{العنف بين الأقران وبرنامج وقائي}

\section{الخلاصة}

بهدف الإشـارة إلى أهمية دراسة مشكلة العنف بين الأقران ومنع حدوثه، سنقدم في

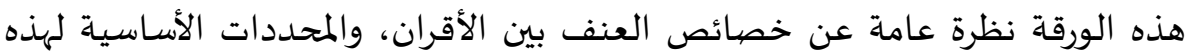

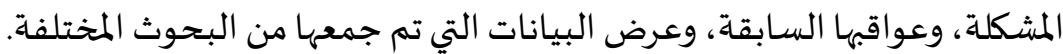

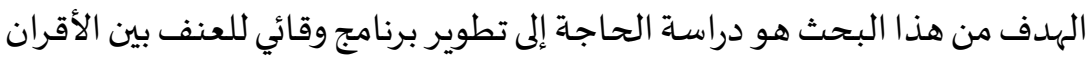
بناءً على عملية تقييم الاحتياجات. هذا في الواقع نموذج للاستثمار في التطور الإيجابي والآمن

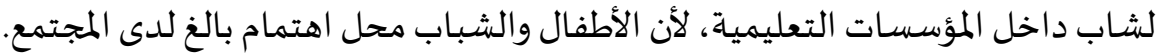
الكلمات المفتاحية: عوامل الخطر، التدخل، الوقاية، العنف الصامت، العنف بين 